\title{
Evidence for a pituitary site of gonadal steroid stimulation of GnRH receptors in female mice*
}

\author{
S. I. Naik, L. S. Young, H. M. Charlton† and R. N. Clayton \\ Department of Medicine, University of Birmingham, Birmingham B15 2TH, and $\uparrow$ Department of \\ Human Anatomy, University of Oxford, South Parks Road, Oxford OXI 3QX,U.K.
}

\begin{abstract}
Summary. Treatment of GnRH-deficient $(h p g)$ female mice with oestradiol-17 $\beta\left(\mathrm{E}_{2}\right)$ for 7 days increased GnRH receptors from $4.1 \pm 0.4 \mathrm{fmol} /$ pituitary (control) to $7.2 \pm 0.7$ $\mathrm{fmol} /$ pituitary (GnRH-treated), and consistently increased pituitary FSH content. Treatment of $h p g$ female mice with $\mathrm{E}_{2}$ plus progesterone (P) for 14 days stimulated $\mathrm{GnRH}$ receptors more than did $\mathrm{E}_{2}$ alone, although values still remained lower than those of normal intact female mice. In contrast, GnRH treatment of intact hpg female mice alone, or combined with $\mathrm{E}_{2}+\mathrm{P}$, increased $\mathrm{GnRH}$ receptors to values similar to those of intact normal female mice. In contrast, the receptor rise after GnRH treatment alone of ovariectomized $h p g$ mice was significantly less than in intact $h p g$ mice similarly treated. However, the combination of $\mathrm{GnRH}+\mathrm{E}_{2}+\mathrm{P}$ treatment of ovariectomized hpg mice increased $\mathrm{GnRH}$ receptors to normal intact female values, indicating the synergistic actions of these hormones on $\mathrm{GnRH}$ receptor up-regulation at the pituitary.

Oestradiol treatment of ovariectomized normal female mice prevented the receptor fall after ovariectomy, and when combined with exogenous GnRH further increased receptors to values identical to those of intact female mice receiving $\mathrm{GnRH}$ alone.

Ovariectomy of $h p g$ mice had no effect on GnRH receptor, serum or pituitary LH and FSH values. There was no change in serum LH concentration after GnRH treatment of $h p g$ female mice, but serum FSH increased and this was accentuated by ovariectomy, indicating that in intact mice an ovarian factor(s) normally inhibits GnRH-stimulated FSH release. This factor did not appear to be an ovarian steroid since serum FSH was not suppressed in intact or ovariectomized GnRH-treated hpg mice concurrently receiving $\mathrm{E}_{2}+\mathrm{P}$ treatment.

These results suggest that: (1) gonadal steroids alone have a major direct stimulatory action on the pituitary to increase GnRH receptors; (2) the oestrogeninduced increase in GnRH receptors is enhanced in the presence of GnRH ; (3) steroids exert inhibitory feedback on gonadotrophin secretion that is mediated at some cellular regulatory locus other than the $\mathrm{GnRH}$-receptor complex.
\end{abstract}

\section{Introduction}

Numerous studies have shown that treatment of females with oestrogens stimulates gonadotrophin secretion (Arimura \& Schally, 1971; Aiyer \& Fink, 1974; Fink, 1979). In monkeys with hypothalamic lesions, and in humans with isolated GnRH deficiency, replacement with pulsatile GnRH results in rising serum oestradiol concentrations which sensitize the pituitary gonadotrophs to subsequent GnRH (Knobil, 1980; Crowley \& McArthur, 1980; Mason et al., 1984; Menon, Butt, Clayton, Logan-Edwards \& Lynch, 1984), confirming a direct pituitary site of oestradiol

\footnotetext{
* Reprint requests to Dr R. N. Clayton.
} 
stimulatory action. In addition, treatment of pituitary cells with oestrogen in vitro sensitizes them to GnRH (Drouin, Lagace \& Labrie, 1976; Debeljuk, Khar \& Jutisz, 1978; Lagace, Massicotte \& Labrie, 1980; Drouin \& Labrie, 1981; Turgeon \& Waring, 1981). This action of oestradiol may in part be due to an increase in pituitary receptors for $\mathrm{GnRH}$, which are known to be elevated at times of high circulating oestrogen concentrations in rodents (Savoy-Moore, Schwartz, Duncan \& Marshall, 1980; Clayton, Solano, Garcia-Vela, Dufau \& Catt, 1980) and monkeys (Adams, Norman \& Spies, 1981). Oestrogen treatment of cultured pituitary cells has also been shown to stimulate directly a modest rise in GnRH receptor levels (Loumaye \& Forni, 1982; Tang, Martellock \& Horiuchi, 1982).

After previous studies (Naik et al., 1985) to explain the post-ovariectomy decrease in GnRH receptors in mice, we suggested an important role for an ovarian factor in the maintenance of GnRH receptors in this species. The aim of the present study was to determine to what extent pituitary GnRH receptors could be directly increased by oestrogen and progesterone treatment of female mice in the presence or absence of GnRH stimulation of the pituitary.

\section{Materials and Methods}

Animals. The normal and hpg (gonadotrophin-deficient) female mice $(\mathrm{C} 3 \mathrm{H} / \mathrm{HeH} / 101 \mathrm{H} \mathrm{Fl}$ hybrid intercrosses, aged 80-190 days, 25-35 g) utilized in this study were obtained from the Department of Human Anatomy, University of Oxford, and were housed under the same conditions as described by Naik, Young, Charlton \& Clayton (1984a).

Hormones. The GnRH agonist analogue [D-Ser $(\mathrm{tBu})^{6}$ des $\left.\mathrm{Gly}^{10}\right]-\mathrm{GnRH} N$-ethylamide (GnRHA) and GnRH used for radioreceptor assay and injection, respectively, were kindly donated by $\mathrm{Dr}$ J. Sandow (Hoechst A.G., Frankfurt, West Germany). Oestradiol-17 $\beta$, progesterone (Sigma Chemical Company, St Louis, MO, U.S.A.) and a combination of the two were dissolved in sesame oil at appropriate concentration and injected subcutaneously (s.c.) in $0.1 \mathrm{ml}$. Other materials were the same as used previously (Naik et al., 1984b).

GnRH receptor assay and radioimmunoassays. The radioreceptor assay for $\mathrm{GnRH}$ was performed as described by Naik et al. (1984a, 1985). The RIAs for serum and pituitary LH, FSH and prolactin concentrations were performed as described by Naik et al. (1984a, b; 1985).

Statistical analysis. When appropriate, differences between means were tested by the MannWhitney U-test or analysis of variance and Student's $t$ test.

\section{Results}

\section{Effect of gonadal steroid treatment in hpg female mice}

Two groups of hpg female mice were injected with $300 \mathrm{ng}$ oestradiol/day or vehicle for 7 days. Two more groups of intact normal female mice were similarly treated. Animals were killed $24 \mathrm{~h}$ after the last injection.

Pituitary GnRH receptors (fmol/pituitary) in $h p g$ females are only $30 \%$ of the value for normal intact females and were almost doubled by oestrogen treatment for 7 days, although not to normal female values (normal female $11 \cdot 7 \pm 0 \cdot 3 ; \mathrm{hpg}$ females $4.1 \pm 0.4 ; \mathrm{hpg}+$ oestradiol $7 \cdot 2 \pm 0.7$; Textfig. 1) (6 mice/group). Ovarian weight was increased from $0.67 \pm 0.1$ to $2.5 \pm 0.6 \mathrm{mg}$ and uterine weight from $7 \cdot 17 \pm 0.3$ to $47.6 \pm 2.8 \mathrm{mg}$ by oestradiol treatment. In normal female mice, oestradiol decreased GnRH receptor content $(11.7 \pm 0.31$ and $9.83 \pm 0.5 \mathrm{fmol} /$ pituitary) although this difference was not significant $(P>0.05)$. Serum LH and FSH concentrations were undetectable $(<24 \mathrm{ng} / \mathrm{ml}$ and $<50 \mathrm{ng} / \mathrm{ml}$, respectively) in untreated hpg animals. After oestradiol treatment 
serum LH and FSH values became detectable. Similar oestradiol treatment of normal female mice did not change serum LH but slightly suppressed $(P<0.05)$ serum FSH from $205 \pm 15$ to $170 \pm 10$ $\mathrm{ng} / \mathrm{ml}$. Pituitary LH and FSH contents remained unchanged in oestradiol treated normal female mice while pituitary FSH was significantly increased $(P<0.01)$ in oestradiol treated $h p g$ females $(1.4 \pm 0.13$ and $0.29 \pm 0.13 \mu \mathrm{g} /$ pituitary $)$.

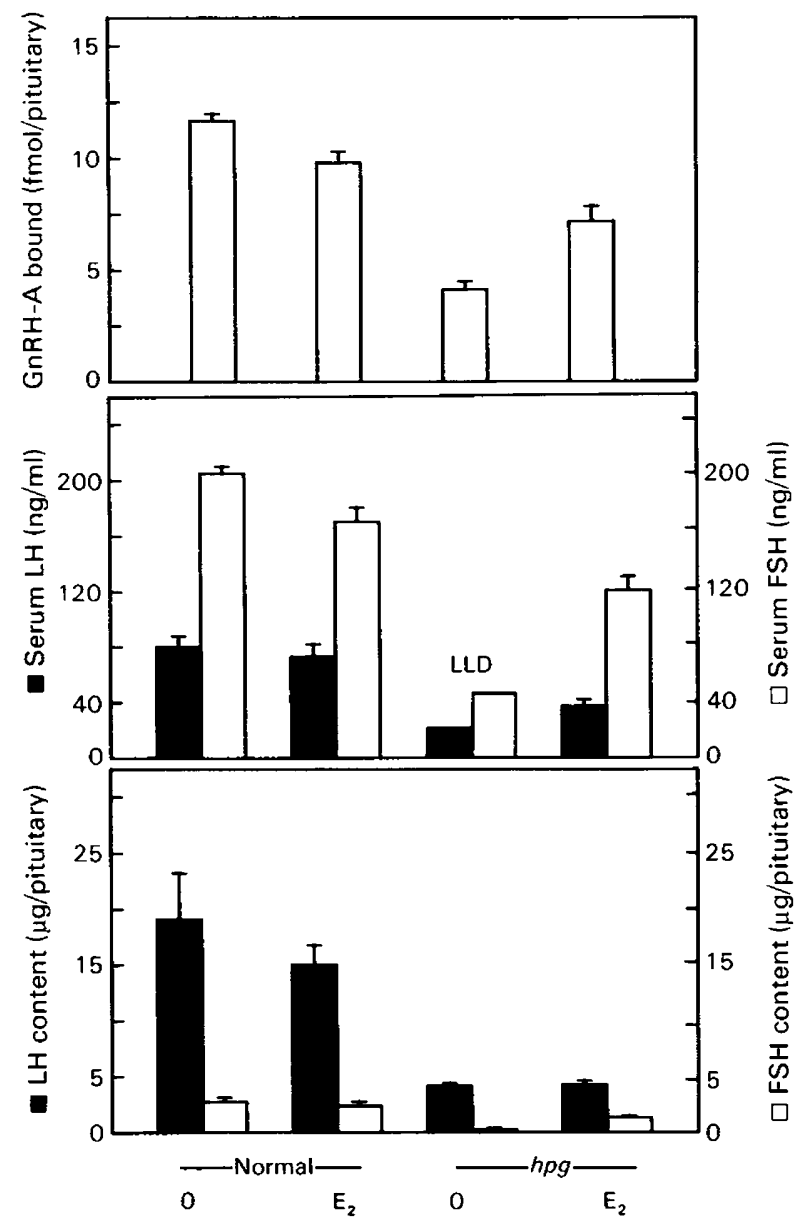

Text-fig. 1. Effect of oestradiol $\left(E_{2}\right)$ treatment ( $300 \mathrm{ng} /$ day for 7 days) on pituitary $\mathrm{GnRH}$ receptors, serum and pituitary $\mathrm{LH}$ and FSH in intact normal and $\mathrm{hpg}$ female mice. Values are mean \pm s.e.m. for 6 animals/group. L.L.D. = lower limit of detection of serum LH $(<24$ $\mathrm{ng} / \mathrm{ml})$ and serum FSH $(50 \mathrm{ng} / \mathrm{ml})$.

In an additional experiment steroid treatment of $h p g$ mice was continued for 14 days, and included an additional two groups of intact normal and $h p g$ female mice injected with $300 \mathrm{ng}$ oestradiol/day together with $375 \mu \mathrm{g}$ progesterone/day. In $\mathrm{hpg}$ females treated with oestradiol alone or oestradiol + progesterone for 14 days, GnRH receptors were increased almost 2-fold (Group $5 v s$ Group 4, $P<0.005$ ) and 3-fold (Group 6 vs Group 4, $P<0.001$ ), respectively (Table 1). The addition of progesterone significantly increased receptor values when compared to oestradiol alone (Group 6 vs Group 5, $P<0.001$ ), values being the same as in intact females treated with both steroids (Group 3 vs Group 6,P>0.1). However, receptor values were reduced $(P<0.005)$ in normal females treated with oestradiol alone or both hormones (Groups 2 and $3 v s$ Group 1). Serum 
and pituitary LH values in hpg females (Groups 5 and 6) were unaltered, but pituitary FSH was significantly $(P<0.05)$ increased above untreated control values (Groups 5 and 6 vs Group 4). There was insufficient serum for measurement of FSH in this experiment. Serum LH was reduced in intact normal females from measurable to undetectable levels in Groups 2 and 3, and pituitary LH was also reduced significantly in Group $2(P<0.05)$ and Group $3(P<0.005)$. There was a similar inhibitory effect on pituitary FSH by treatment with oestradiol alone (Group 2 vs Group 1, $P<0.001$ ) or combined with progesterone (Group $3 v s$ Group 1) in normal female mice. Serum and pituitary prolactin were not different in mice in Groups 1, 2 and 3. However, in $h p g$ females (Groups 5 and 6) serum and pituitary prolactin values were increased 2-fold and were similar to those of normal intact females (Group 1) although the values in intact $h p g$ mice (Group 4) were half those of intact normal females.

Table 1. Effect of treatment (for 14 days) of intact normal and hpg female mice with oestradiol-17ß $\left(\mathrm{E}_{2}\right)$ and progesterone (P)

\begin{tabular}{|c|c|c|c|c|c|c|}
\hline \multirow[b]{2}{*}{ Groups } & \multirow{2}{*}{$\begin{array}{c}\text { GnRH } \\
\text { receptors } \\
\text { (fmol/pituitary) }\end{array}$} & \multirow{2}{*}{$\underset{(\mathrm{Sg} / \mathrm{ml})}{\text { Serum LH }}$} & \multirow{2}{*}{$\begin{array}{l}\text { Serum } \\
\text { prolactin } \\
(\mathrm{ng} / \mathrm{ml})\end{array}$} & \multicolumn{3}{|c|}{ Pituitary content ( $\mu \mathrm{g} /$ pituitary) } \\
\hline & & & & LH & FSH & Prolactin \\
\hline (1) Normal female + vehicle & $13.40 \pm 1.25$ & $32 \cdot 3 \pm 8 \cdot 0$ & $4.5 \pm 0.34$ & $27 \cdot 21 \pm 6 \cdot 0$ & $3.03 \pm 0.72$ & $0.75 \pm 0.07$ \\
\hline (2) Normal female $+E_{2}$ & $9.24 \pm 0.62$ & $<20$ & $5 \cdot 6 \pm 0.56$ & $17 \cdot 9 \pm 1 \cdot 1$ & $1.45 \pm 0.17$ & $0.8 \pm 0.06$ \\
\hline (3) Normal female $+E_{2}+P$ & $9 \cdot 4 \pm 1 \cdot 8$ & $<20$ & $5 \cdot 2 \pm 0 \cdot 64$ & $9 \cdot 2 \pm 1 \cdot 7$ & $1.83 \pm 0.25$ & $0.8 \pm 0.06$ \\
\hline (4) hpg female + vehicle & $3 \cdot 2 \pm 0 \cdot 24$ & $<20$ & $2 \cdot 4 \pm 0 \cdot 5$ & $7 \cdot 2 \pm 0 \cdot 57$ & $1.42 \pm 0.08$ & $0.33 \pm 0.02$ \\
\hline (5) $h p g$ female $+\mathrm{E}_{2}$ & $5 \cdot 41 \pm 0 \cdot 27$ & $<20$ & $5 \cdot 6 \pm 0.43$ & $8 \cdot 1 \pm 0 \cdot 11$ & $2 \cdot 04 \pm 0 \cdot 19$ & $0.70 \pm 0.02$ \\
\hline (6) $h p g$ female $+\mathrm{E}_{2}+\mathrm{P}$ & $8.65 \pm 1.0$ & $<20$ & $5 \cdot 7 \pm 1 \cdot 2$ & $7.6 \pm 0.61$ & $2 \cdot 16 \pm 0 \cdot 47$ & $0.55 \pm 0.02$ \\
\hline
\end{tabular}

Values are mean \pm s.e.m. for 6 mice/group. See text for significance of differences between groups.

GnRH receptor values are lower in intact females than in those in Table 2 since they were measured with a nonsaturating concentration of ligand to be comparable with the hpg animals (see 'Methods').

Uterine weights of hpg females treated for 14 days with oestradiol were increased 9-fold compared with untreated $h p g$ controls $(62.3 \pm 3.6$ and $7.4 \pm 2 \mathrm{mg})$ and were also significantly greater $(P<0.05)$ than values after combined steroid treatment $(46.9 \pm 3 \mathrm{mg})$. Similarly, in intact normal females, oestradiol treatment alone increased $(P<0.05)$ the uterine weights $(260 \pm 44$ and $154 \pm 26 \mathrm{mg}$ ) while concurrent treatment with progesterone had no significant effect on uterine weights $(169 \pm 8.2 \mathrm{mg})$.

\section{Effect of oestradiol-17ß alone or combined with GnRH in ovariectomized female mice}

Groups of ovariectomized mice were injected s.c. with (i) GnRH (60 ng every 8 h), (ii) GnRH ( $60 \mathrm{ng}$ every $8 \mathrm{~h}$ ) + oestradiol ( $300 \mathrm{ng}$ once daily), (iii) oestradiol alone ( $300 \mathrm{ng} /$ day), or (iv) vehicle (sesame oil), starting at the time of ovariectomy and continued for 4 days. Intact normal female mice were also injected with GnRH alone $(60 \mathrm{ng}$ every $8 \mathrm{~h}$ ) or vehicle for the same time.

The results are shown in Text-fig. 2. Previous observations (Naik et al., 1984b) have shown that treatment of ovariectomized mice with $300 \mathrm{ng}$ oestradiol/day for 7 days largely reversed the fall in GnRH receptors whereas on this occasion values in mice treated with the same dose for 4 days were similar to those of controls $(62.3 \pm 4$ and $63.3 \pm 3.4 \mathrm{fmol} /$ pituitary respectively). Receptor values were further increased to $80.4 \pm 4.3 \mathrm{fmol} /$ pituitary by concurrent $\mathrm{GnRH}$ treatment, a value similar to that of intact females receiving $\mathrm{GnRH}$ alone $(84.6 \pm 3.4 \mathrm{fmol} /$ pituitary). Treatment of 
ovariectomized females with $\mathrm{GnRH}$ alone was without effect on the receptor levels $(48 \cdot 2 \pm 3 \cdot 0$ and $49.5 \pm 4.0 \mathrm{fmol} /$ pituitary). However, the fall in $\mathrm{GnRH}$ receptors in this experiment 4 days after ovariectomy was less than in previous studies (Naik et al., 1984b, 1985) in which values at 7 days after ovariectomy had fallen by $>50 \%$.
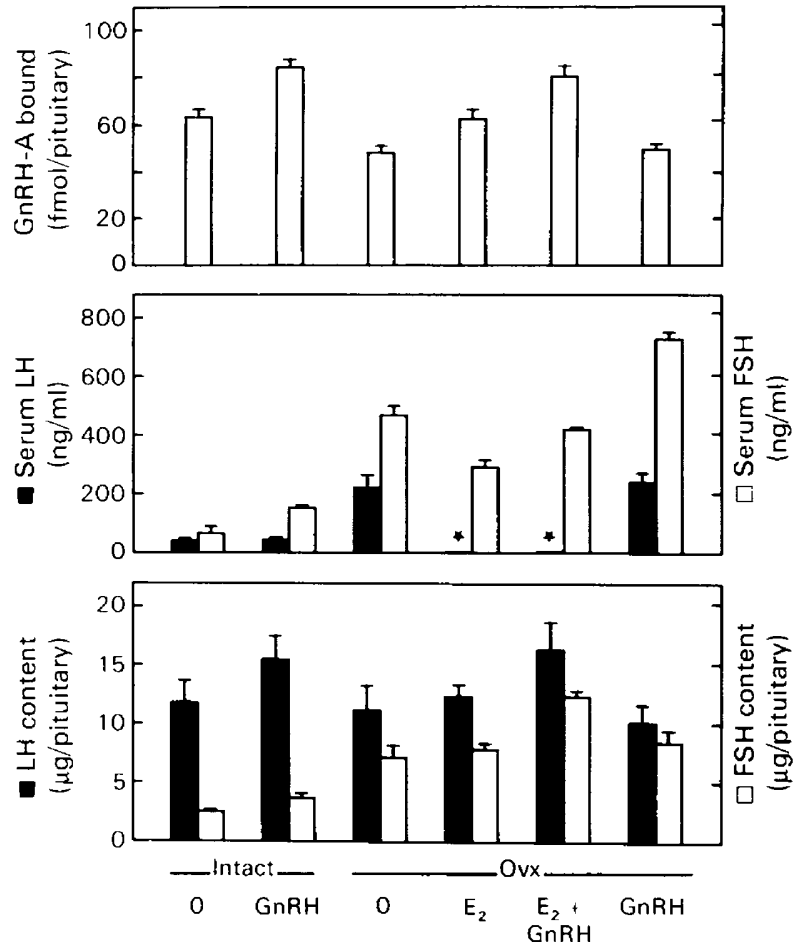

Text-fig. 2. GnRH receptors, (a), serum LH and FSH concentrations (b) and pituitary LH and FSH content (c) in ovariectomized female mice after concurrent treatment with a daily subcutaneous injection of oestradiol $\left(\mathrm{E}_{2}\right)(300 \mathrm{ng})$ and 3 injections of GnRH (60 ng every $8 \mathrm{~h}$ ), beginning at the time of ovariectomy and continued for 4 days. Values are mean \pm s.e.m. for 6 animals/group. ${ }^{*}$ Not detectable ( $<25 \mathrm{ng} \mathrm{LH} / \mathrm{ml}$ serum).

Pituitary FSH and serum and pituitary LH values in intact females were unaffected by GnRH treatment alone $8 \mathrm{~h}$ after the last injection, while serum FSH was doubled by such treatment $(P<$ $0 \cdot 01)$. In ovariectomized females, high concentrations of serum LH $(221 \pm 42 \mathrm{ng} / \mathrm{ml})$ remained unaltered by $\mathrm{GnRH}$, but $\mathrm{LH}$ was undetectable by oestradiol treatment alone or combined with GnRH. However, serum FSH concentrations in ovariectomized females $(467 \pm 30 \mathrm{ng} / \mathrm{ml})$ were increased to $728 \pm 25 \mathrm{ng} / \mathrm{ml}$ by GnRH alone $(P<0.01)$, although this increase was not apparent in the GnRH plus oestradiol treated animals $(419 \pm 9 \cdot 5 \mathrm{ng} / \mathrm{ml})$, and was suppressed to $293 \pm 23 \mathrm{ng} / \mathrm{ml}$ in mice treated with oestradiol alone. Pituitary LH content remained unchanged by oestradiol or GnRH treatment alone, while combined treatment stimulated the synthesis of both pituitary LH and FSH $(P<0.05)$ in ovariectomized females.

Effect of oestradiol plus progesterone alone or combined with $\mathrm{GnRH}$ in intact and ovariectomized hpg female mice

Groups of intact or ovariectomized $h p g$ and normal female mice were injected with (i) vehicle (PBS/BSA and sesame oil), (ii) $60 \mathrm{ng}$ GnRH s.c. 5 times per day at 4-h intervals for 5 days 
commencing at the time of ovariectomy, (iii) oestradiol ( $300 \mathrm{ng} /$ day) and progesterone ( $375 \mu \mathrm{g} /$ day) for 5 days, or (iv) combined GnRH and steroids as in treatments (ii) and (iii). Both steroids were given because the combination produced a larger increase in GnRH receptors than did oestradiol alone (Table 1). Animals were killed $24 \mathrm{~h}$ after the last steroid injection and 10-12 $\mathrm{h}$ after the last GnRH injection.

Pituitary GnRH receptors in intact $h p g$ female mice were only $34 \%$ of normal intact female values (Group 5 vs Group 1), and were doubled by steroid treatment (Groups 9 and 5), although values did not reach the normal intact control levels (Group 9 vs Group 1, $P<0.01$ ) (Table 2). Ovariectomy of $h p g$ females did not change GnRH receptor values (Group 6 vs Group 5, N.S.), in contrast to the effect of ovariectomy in normal females in which receptor values fell by about $50 \%$ (Group 3 vs Group 1). The same increase in GnRH receptors occurred in the ovariectomized hpg females given steroids (Group 10) but the absolute receptor value was not significantly different from that in intact $h p g$ mice treated with steroids (Group 9). However, the concurrent treatment of intact or ovariectomized hpg females with steroids and GnRH increased receptors to values comparable to those of intact hpg females treated only with GnRH (Groups 12 and 11 vs Group 7, N.S.). Values for Groups 11 and 12 were significantly higher than those for ovariectomized $h p g$ mice treated with GnRH alone (Group 8, $P<0.05$ ). None of these treatments of $h p g$ mice led to detectable serum LH concentrations. However, as previously observed (Naik et al., 1985; Text-fig. 1), serum LH but not serum FSH in intact and ovariectomized normal female mice was markedly suppressed by multiple GnRH injections (Group 2 vs Group 1, $P<0.05$; Group 4 vs Group 3, $P<$ $0.001)$ and there was a reduction of pituitary LH content in ovariectomized females $(P<0.05)$. This suppression of serum $\mathrm{LH}$ in intact females by multiple GnRH injections was associated with decreased uterine and ovarian weights $(P<0.05)$ (Table 2). Pituitary FSH was not significantly changed by GnRH treatment, although in untreated ovariectomized females pituitary FSH was increased 3-fold compared to values in untreated intact females.

Ovariectomy alone of $h p g$ mice had no significant effect on serum and pituitary LH and FSH contents. Serum LH in all hpg female groups, however treated, remained undetectable, while serum FSH was elevated to detectable values by GnRH alone or when combined with steroid treatment. Serum FSH concentrations were significantly higher $(P<0.001)$ in the ovariectomized GnRHtreated mice (Groups 8 and 12) than in those of intact hpg female animals similarly treated (Group 7), while pituitary LH and FSH contents were not significantly altered by ovariectomy. However, pituitary LH contents in intact and ovariectomized hpg mice treated with GnRH (Groups 7 and 8) were significantly $(P<0.05)$ reduced compared to those in vehicle-injected controls (Groups 5 and 6). This suggests that the treatment effectively released $\mathrm{LH}$, even though serum LH was unmeasurable, presumably because the animals were killed $10 \mathrm{~h}$ after the last GnRH injection. In contrast, pituitary FSH content was increased markedly (4-5-fold) by the GnRH injections alone (Groups 8 and 7 vs Group 5, $P<0.001$ ) to a value which was comparable to that produced by combined treatment with GnRH and steroids (Group 11), and significantly higher than with treatment with steroids alone (Groups 7 and 8 vs Groups 9 and $10, P<0.001$ ). The highest pituitary FSH content was seen in ovariectomized $h p g$ females treated with steroids + GnRH (Group $12 v s$ Group 11, $P<0.02$ ).

Significant growth of ovaries and uteri occurred after GnRH injections (Group 7 ss Group 5, $P<0.01$ ), but steroids alone produced a greater increase in uterine weight (Table 2). Combined treatment of steroids $+\mathrm{GnRH}$ produced a bigger increase in ovarian and uterine weights than did steroids alone $(P<0.01)$ (Table 2$)$.

\section{Discussion}

The results of previous experiments (Naik et al., 1985) indicated that the pituitary GnRH receptor fall after ovariectomy of mice was not primarily related to changes in endogenous GnRH secretion. Rather, this receptor fall was related to removal of gonadal hormones and we suggested that 
Table 2. Effect of oestradiol $\left(E_{2}\right)$ plus progesterone $(P)$ alone or combined with $\mathrm{GnRH}(60 \mathrm{ng} / \mathrm{injection}$, 5 times/day for 5 days) in intact and ovariectomized (OVX) normal and $h p g$ female mice

\begin{tabular}{|c|c|c|c|c|c|c|c|}
\hline \multirow[b]{2}{*}{ Groups } & \multirow{2}{*}{$\begin{array}{c}\text { GnRH } \\
\text { receptor } \\
\text { (fmol/pituitary }\end{array}$} & \multicolumn{2}{|c|}{ Serum conc. (ng/ml) } & \multicolumn{2}{|c|}{$\begin{array}{l}\text { Pituitary content } \\
(\mu \mathrm{g} / \text { pituitary })\end{array}$} & \multirow{2}{*}{$\begin{array}{l}\text { Ovarian } \\
\text { wt (mg) }\end{array}$} & \multirow{2}{*}{$\begin{array}{l}\text { Uterine } \\
\text { wt (mg) }\end{array}$} \\
\hline & & LH & FSH & LH & FSH & & \\
\hline $\begin{array}{l}\text { (1) Intact normal } \\
\text { female + vehicle }\end{array}$ & $12 \cdot 07 \pm 0 \cdot 27$ & $34 \cdot 3 \pm 7 \cdot 9$ & $61 \cdot 0 \pm 14 \cdot 3$ & $30 \cdot 3 \pm 3 \cdot 6$ & $2.94 \pm 0.43$ & $14 \cdot 0 \pm 0 \cdot 9$ & $131 \cdot 5 \pm 16 \cdot 0$ \\
\hline $\begin{array}{l}\text { (2) Intact normal } \\
\text { female + GnRH }\end{array}$ & $15 \cdot 18 \pm 0 \cdot 63$ & $12 \cdot 8 \pm 5 \cdot 6$ & $69 \pm 17$ & $34 \cdot 6 \pm 2 \cdot 6$ & $4.6 \pm 0.53$ & $10 \cdot 8 \pm 0 \cdot 2$ & $73 \cdot 1 \pm 5 \cdot 9$ \\
\hline $\begin{array}{l}\text { (3) OVX normal } \\
\text { female + vehicle }\end{array}$ & $6 \cdot 04 \pm 0 \cdot 26$ & $266 \pm 67$ & $293 \pm 5 \cdot 1$ & $39 \cdot 8 \pm 5 \cdot 8$ & $10.03 \pm 0.52$ & & \\
\hline $\begin{array}{l}\text { (4) OVX normal } \\
\text { female + GnRH }\end{array}$ & $6.5 \pm 0.96$ & $27 \pm 14 \cdot 3$ & $312 \pm 8 \cdot 5$ & $26 \cdot 3 \pm 2 \cdot 2$ & $11 \cdot 9 \pm 0 \cdot 6$ & & \\
\hline $\begin{array}{l}\text { (5) Intact hpg } \\
\text { female + vehicle }\end{array}$ & $4 \cdot 86 \pm 0 \cdot 3$ & ND & ND & $7 \cdot 3 \pm 0.9$ & $1 \cdot 21 \pm 0 \cdot 18$ & $0.75 \pm 0.1$ & $6 \cdot 3 \pm 0 \cdot 3$ \\
\hline $\begin{array}{l}\text { (6) OVX hpg } \\
\text { female + vehicle }\end{array}$ & $5 \cdot 0 \pm 0.3$ & ND & ND & $7.9 \pm 0.8$ & $1 \cdot 37 \pm 0 \cdot 18$ & & \\
\hline $\begin{array}{l}\text { (7) Intact hpg } \\
\text { female + GnRH }\end{array}$ & $11.9 \pm 0.44$ & ND & $58 \pm 5$ & $5 \cdot 17 \pm 0 \cdot 34$ & $5.52 \pm 0.35$ & $2 \cdot 3 \pm 0 \cdot 3$ & $11 \cdot 5 \pm 2 \cdot 2$ \\
\hline $\begin{array}{l}\text { (8) OVX hpg } \\
\text { female + GnRH }\end{array}$ & $8.21 \pm 0.91$ & ND & $160 \pm 18$ & $4 \cdot 23 \pm 0 \cdot 26$ & $6.6 \pm 0.47$ & & \\
\hline $\begin{array}{l}\text { (9) Intact } h p g \\
\text { female }+E_{2}+P\end{array}$ & $8 \cdot 27 \pm 0.68$ & ND & ND & $8 \cdot 3 \pm 0 \cdot 5$ & $2.59 \pm 0.21$ & $2 \cdot 3 \pm 0.27$ & $36 \cdot 2 \pm 2 \cdot 5$ \\
\hline $\begin{array}{l}\text { (10) OVX hpg } \\
\text { female + } E_{2}+P\end{array}$ & $8.07 \pm 0.56$ & ND & ND & $9.92 \pm 0.36$ & $3 \cdot 21 \pm 0 \cdot 17$ & & \\
\hline $\begin{array}{l}\text { (11) Intact hpg } \\
\text { female }+\mathrm{E}_{2}+\mathrm{P} \\
+\mathrm{GnRH}\end{array}$ & $13.37 \pm 0.79$ & ND & $80 \cdot 5 \pm 13$ & $8.84 \pm 0.8$ & $6.39 \pm 0.54$ & $6 \cdot 37 \pm 2 \cdot 3$ & $63 \cdot 2 \pm 9 \cdot 5$ \\
\hline $\begin{array}{l}\text { (12) OVX hpg } \\
\text { female }+\mathrm{E}_{2}+\mathrm{P} \\
+\mathrm{GnRH}\end{array}$ & $11 \cdot 15 \pm 1 \cdot 08$ & ND & $225 \pm 13$ & $7 \cdot 12 \pm 0 \cdot 41$ & $9.32 \pm 0.64$ & & \\
\hline
\end{tabular}

Values are means \pm s.e.m. for 6 mice/group. See text for significance of differences between groups.

$\mathrm{ND}$, not detectable ( $<5 \mathrm{ng} \mathrm{LH} / \mathrm{ml}$ serum; $<50 \mathrm{ng} \mathrm{FSH} / \mathrm{ml}$ serum).

oestrogen, particularly, might have an important direct stimulatory action on the pituitary to maintain GnRH receptors, while concomitantly inhibiting gonadotrophin secretion. The results of the present experiments in the GnRH-deficient, hpg, female mouse provide confirmation of a stimulatory role for oestradiol on GnRH receptors, acting directly on the gonadotroph. Furthermore, oestradiol stimulation of GnRH receptors in hpg mice is augmented by progesterone, in agreement with our previous finding that this steroid facilitates the oestradiol-induced receptor increase in ovariectomized normal mice (Naik et al., 1984b). These in-vivo data are in agreement with in-vitro data obtained by Loumaye \& Forni (1982) and Tang et al. (1982) who showed a modest stimulatory action of oestrogen on GnRH receptors in cultured rat pituitary cells. The present observations in mice provide support for the earlier hypothesis (Clayton et al., 1980; Savoy-Moore et al., 1980) that the GnRH receptor rise between metoestrus and dioestrus in rats could be a 
consequence of rising serum oestradiol levels which directly induce GnRH receptors without influencing endogenous GnRH secretion. Oestradiol-induced increases in GnRH receptors accompanied by increased pituitary LH content (Clayton et al., 1980) could sensitize the gonadotroph to possible subsequent increases in endogenous GnRH secretion on the afternoon of pro-oestrus (Sarkar, Chiappa \& Fink, 1976).

In intact female mice we have found suppression of $\mathrm{GnRH}$ receptors and serum gonadotrophins with combined oestradiol and progesterone treatment (Naik et al., 1985). The present results confirm those observations and identify the hypothalamus as the likely site for this inhibitory steroid action on GnRH receptors, since values were reduced to those found in the GnRH-deficient hpg mice treated similarly.

The present experiments also show that while gonadal steroids increased GnRH receptors in hpg female mice the values did not reach those of normal female controls and there was no stimulation by the steroids of serum gonadotrophin levels. This indicates a requirement for GnRH for maintenance of a 'normal' GnRH receptor complement as well as for synthesis and secretion of gonadotrophins. GnRH is therefore required for maintaining GnRH receptor and gonadotroph function in normal female mice, and exerts a synergistic action with oestradiol on receptor regulation (Naik et al., 1985). Evidence for this is provided by the effectiveness of combined oestradiol + GnRH treatment in ovariectomized normal mice in increasing GnRH receptors to the same values as seen in intact normal mice treated with GnRH alone. Similar oestrogen induction of GnRH receptors has been obtained in ovariectomized monkeys (Adams et al., 1981) and rats (Barkan, Regiani, Duncan \& Marshall, 1983), although the nature of these studies did not allow distinction between a pituitary or hypothalamic site of action. Our present studies with the GnRH-deficient mouse showed that GnRH plus gonadal steroids increased GnRH receptors to intact normal female values, providing direct evidence that the major site for the stimulatory action of oestradiol on GnRH receptors is at the pituitary. Furthermore, homologous ligand induction of GnRH receptors in hpg female mice was attenuated by prior ovariectomy, again providing evidence for a synergistic action of the two hormones at the pituitary. The view that gonadal steroid hormones are the primary modulators of gonadotroph function in mice, while GnRH subserves a permissive secondary role, is in accord with conclusions derived from studies of monkeys with hypothalamic lesions (Knobil, 1980) and GnRH-deficient women (Crowley \& McArthur, 1980) in whom ovulatory cycles are re-established by unvarying dose and frequency of GnRH administration.

However, in rats, although oestrogen clearly sensitizes the pituitary to GnRH (Greely, Allen \& Mahesh, 1975; De Koning, Van Dieten \& Van Rees, 1976; Drouin et al., 1976) by direct action in vitro, the role of gonadal steroids as the primary hormonal regulation of $\mathrm{GnRH}$ receptors is not so clear. In contrast to events in mice, GnRH receptors rise after ovariectomy and this can be prevented or reversed by oestrogen treatment (Clayton \& Catt, 1981), as well as by GnRH immunoneutralization (R. N. Clayton, unpublished observations).

In agreement with previous in-vivo data (Charlton et al., 1983), repetitive GnRH treatment of hpg female mice was able to stimulate growth of the uterus and ovaries, suggesting an increase in endogenous steroid secretion. Although we could not detect any rise in serum LH in these animals, presumably because the animals were killed $10 \mathrm{~h}$ after the last $\mathrm{GnRH}$ injection, evidence for $\mathrm{LH}$ release was provided by depletion of pituitary $\mathrm{LH}$ content in intact and ovariectomized $h p g$ mice treated with GnRH. Serum FSH was, however, measurable in hpg mice treated with GnRH and values were much higher if the animals were ovariectomized. This indicates that an endogenous gonadal factor acts on the pituitary to inhibit FSH release in response to GnRH, although it did not inhibit the GnRH stimulation of pituitary FSH content. This factor is unlikely to be a steroid since treatment with steroids and GnRH did not suppress serum FSH levels; if anything these were slightly increased.

A consistent doubling of pituitary FSH concentration was observed after treatment with oestradiol alone or when combined with progesterone even in the absence of GnRH, and this 
seemed to be greater in ovariectomized $h p g$ mice, again suggesting the elaboration by the ovaries of a factor which suppresses FSH synthesis. No such stimulation of pituitary LH concentration was observed. The direct stimulation of FSH synthesis by gonadal steroids provides additional evidence that regulation of FSH secretion and synthesis is to some extent independent of GnRH stimulation.

Naik et al. (1985) found desensitization of serum $\mathrm{LH}$ release in intact and ovariectomized females in response to 5 injections of GnRH for 4 days, although $\mathrm{GnRH}$ receptors remained unchanged in ovariectomized females while $>30 \%$ increase occurred in intact females. Similar consistent results were obtained in the present study with the same treatment (Table 2). However, in another study, when GnRH was given 3 times a day for 4 days (Text-fig. 2), no desensitization of LH release was observed, therefore strengthening the concept that the pituitary gonadotrophin responses to GnRH depend upon the frequency of exposure to the decapeptide. The dissociation between GnRH and steroid stimulation of pituitary GnRH receptor changes and inhibition of gonadotrophin secretion indicate that the negative feedback action of oestrogen is mediated at some regulatory locus other than the $\mathrm{GnRH}$-receptor complex. Nevertheless, it remains possible that a part of the oestrogen augmentation of GnRH-stimulated LH release (Aiyer \& Fink, 1974; De Koning et al., 1976; Tang et al., 1982) is mediated by the increased number of GnRH receptors. However, the precise relationship between $\mathrm{GnRH}$ receptor changes and pituitary responsiveness to $\mathrm{GnRH}$ in vivo remains to be determined.

Our present results demonstrate that there is a major stimulatory action of gonadal steroids on GnRH receptors at the pituitary level in mice. In mice, GnRH-related increases in GnRH receptors are secondary to the stimulation of oestrogen secretion by the GnRH, and there is a synergistic action of both hormones in the maintenance of a normal complement of GnRH receptors. Despite this, under the conditions of these experiments, there is no close correlation between oestradiol-induced GnRH receptor increases and basal serum gonadotrophin concentrations.

The work was supported by grants from the M.R.C. (R.N.C. and H.M.C.), the Central Birmingham Health District Special Trustees (L.S.Y.) and the Government of Pakistan (S.I.N.).

\section{References}

Adams, T.E., Norman, R.L. \& Spies, H.G. (1981) Gonadotropin-releasing hormone receptor binding and pituitary responsiveness in estradiol primed monkeys. Science, N.Y. 213, 1388-1390.

Aiyer, M.S. \& Fink, G. (1974) The role of sex steroids in modulating the responsiveness of anterior pituitary gland to luteinizing hormone releasing factor in the female rat. $J$. Endocr. 62, 553-572.

Arimura, A. \& Schally, A.V. (1971) Augmentation of pituitary responsiveness to $\mathrm{LH}$ releasing hormone (LH-RH) by estrogen. Proc. Soc. exp. Biol. Med. 136, 290-293.

Barkan, A.L., Regiani, S.R., Duncan, J.A. \& Marshall, J.C. (1983) Pituitary gonadotrophin releasing hormone receptors during gonadotropin surges in ovarectomized estradiol-treated rats. Endocrinology 112, 1042-1048.

Charlton, H.M., Halpin, D.M.G., Iddon, C., Rosie, R., Levy, G., McDowell, I.F.W.M., Megson, A., Morrison, J.F., Bramwell, A., Speight, A., Ward, B.J., Broadhead, J., Davey-Smith, G. \& Fink, G. (1983) The effect of daily administration of single and multiple injections of gonadotropin releasing hormone on pituitary and gonadal function in the hypogonadal (hpg) mouse. Endocrinology 113, 535544.
Clayton, R.N. \& Catt, K.J. (1981) Regulation of pituitary gonadotropin releasing hormone receptors by gonadal hormones. Endocrinology 108, 887-895.

Clayton, R.N., Solano, A.R., Garcia-Vela, A., Dufau, M.L. \& Catt, K.J. (1980) Regulation of pituitary receptors for gonadotropin releasing hormone during rat estrous cycle. Endocrinology 107, 699-706.

Crowley, W.F. \& McArthur, J.W. (1980) Stimulation of normal menstrual cycle in Kallman's syndrome by pulsatile administration of luteinising hormone releasing hormone (LHRH). J. clin. Endocr. Metab. 51, 173-175.

Debeljuk, L., Khar, A. \& Jutisz, M. (1978) Effects of gonadal steroids and cycloheximide on the release of gonadotrophins by rat pituitary cells in culture. $J$. Endocr. 77, 409-415.

De Koning, J., Van Dieten, J.A.M.J. \& Van Rees, G.P. (1976) Inhibitory and augmentative effects of oestradiol on LH-RH-induced release of LH by anterior pituitary glands from intact female rats in vitro. Molec. cell. Endocr. 5, 321-330.

Drouin, J. \& Labrie, F. (1981) Interactions between $17 \beta$ estradiol and progesterone in the control of luteinizing hormone and follicle stimulating hormone release in rat anterior pituitary cells in culture. Endocrinology 108, 52-57. 
Drouin, J., Lagace, I. \& Labrie, F. (1976) Estradiol induced increase of the $\mathrm{LH}$ responsiveness to $\mathrm{LH}$ releasing hormone ( $\mathrm{LHRH}$ ) in rat anterior pituitary cells in culture. Endocrinology 99, 1477-1481.

Fink, G. (1979) Feedback actions of target hormones on hypothalamus and pituitary with special reference to gonadal steroids. Ann. Rev. Physiol. 41, 571-585.

Greeley, G.H., Allen, M.B. \& Mahesh, V.B. (1975) Potentiation of luteinizing hormone release by estradiol at the level of the pituitary. Neuroendocrinology 18, 233-24l.

Knobil, E. (1980) The neuroendocrine control of the menstrual cycle. Recent Prog. Horm. Res. 36, 53-88.

Legace, L., Massicotte, J. \& Labrie, F. (1980) Acute stimulatory effects of progesterone on luteinizing hormone and follicle-stimulating hormone release in rat anterior pituitary cells in culture. Endocrinology 106, 684-689.

Loumaye, E. \& Forni, L. (1982) Regulatory actions of $17 \beta$-estradiol and progesterone upon pituitary GnRH receptors in vitro. Endocrinology 110, Suppl., p. 286, Abstr. 825.

Mason, P., Adams, J., Morris, D.V., Tucker, M., Price, J., Voulgaris, Z., Van Der Spuy, Sutherland, I., Chambers, G.R., White, S., Wheeler, M.J. \& Jacobs, H.S. (1984) Induction of ovulation with pulsatile luteinising hormone releasing hormone. Br. med. J. 288, 181-185.

Menon, J., Butt, W.R., Clayton, R.N., Logan-Edwards, R. \& Lynch, S.S. (1984) Pulsatile administration of GnRH for the treatment of hypogonadotrophin hypogonadism. Clin. Endocr. 21, 223-232.
Naik, S.I., Young, L.S., Charlton, H.M. \& Clayton, R.N. (1984a) Pituitary gonadotropin releasing hormone receptor regulation in mice. I. Males. Endocrinology 115, 106-113.

Naik, S.I., Young, L.S., Charlton, H.M. \& Clayton, R.N. (1984b) Pituitary gonadotropin-releasing hormone receptor regulation in mice. II. Females. Endocrinology 115, 114-120.

Naik, S.I., Young, L.S., Saade, G., Kujore, A., Charlton, H.M. \& Clayton, R.N. (1985) Role of GnRH in the regulation of pituitary $\mathrm{GnRH}$ receptors in female mice. J. Reprod. Fert. 74, 605-614.

Sarkar, D.K., Chiappa, S.A. \& Fink, G. (1976) Gonadotrophin-releasing hormone surge in proestrous rats. Nature, Lond. 264, 461-463.

Savoy-Moore, R.T., Schwartz, N.B., Duncan, J.A. \& Marshall, J.C. (1980) Pituitary gonadotrophin releasing receptors during rat estrous cycle. Science, $N . Y$. 209, 942-944.

Tang, I.K., Martellock, A.C. \& Horiuchi, J.K. (1982) Estradiol stimulation of $\mathrm{LH}$ response to LHRH and LHRH binding in pituitary cultures. Am. J. Physiol. 242, E 392-397.

Turgeon, J.L. \& Waring, D.W. (1981) Acute progesterone and $17 \beta$-estradiol modulation of luteinizing hormone secretion by pituitaries of cycling rats superfused in vitro. Endocrinology 108, 413-419.

Received 18 October 1984 